\title{
Preliminary studies on the effect of rebamipide against the trypsin and egg-albumin induced experimental model of asthma
}

\author{
PRIYANSHEE GOHIL ${ }^{1, *}$ \\ HIMANI THAKKAR ${ }^{1}$ \\ UNNATI GOHIL ${ }^{2}$ \\ SHRIKALP DESHPANDE ${ }^{1}$ \\ ${ }^{1}$ Department of Pharmacology \\ K.B. Institute of Pharmaceutical Education \\ and Research Gandhinagar, Gujarat, India \\ ${ }^{2}$ Kidney and Urology Hospital \\ Interstitial Cystitis Center Ahmedabad \\ Gujarat, India
}

Accepted September 1, 2011
The present investigation was carried out to study the effect of rebamipide in experimentally induced bronchial asthma in mice. Trypsin and egg-albumin induced chronic model of asthma was used and various parameters were measured on the $35^{\text {th }}$ day. The asthmatic control group showed lower level of haemoglobin saturation with oxygen, tidal volume, airflow rate and higher respiratory rate, serum bicarbonate level, eosinophil count in bronchoalveolar lavage fluid and histamine level compared to the normal control group. Dexamethasone and rebamipide treated groups showed the return of all the above parameters towards normal values. Histopathological examination of lungs showed more prominent alveolar and muscular layer destruction in the asthmatic control group than in dexamethasone and rebamipide treated groups. Rebamipide showed a beneficial effect and might be used for the treatment of bronchial asthma.

Keywords: asthma, rebamipide, trypsin, histamine

Asthma is a chronic inflammatory disease of the airways in which many cell types play a role, in particular mast cells, eosinophils and T lymphocytes. In susceptible individuals, inflammation causes recurrent episodes of wheezing, breathlessness, chest tightness and cough, particularly at night and/or early morning. Inflammation causes an associated increase in airway responsiveness to a variety of stimuli (1). Recruitment of peripheral blood cells into inflamed airways is the result of adhesive interactions between circulating inflammatory and microvascular endothelial cells via the production of proinflammatory mediators, cytokines and chemokines, and the expression of cell surface adhesion molecules (2).

Rebamipide, an amino acid derivative of $2(1 H)$-quinolinone (Fig. 1), is used for mucosal protection, healing of gastroduodenal ulcers, and treatment of gastritis, colitis and inflammatory bowel disease (3-5). Rebamipide inhibits the NF- $\kappa \mathrm{B}$, expression of various adhesion molecules as well as the production of various inflammatory mediators (IL-1 $\alpha$,

\footnotetext{
* Correspondence; e-mail: priyansheeg@yahoo.co.in
} 
P. Gohil et al.: Preliminary studies on the effect of rebamipide against the trypsin and egg-albumin induced experimental model of asthma, Acta Pharm. 61 (2011) 427-433.

IL-8, TNF- $\alpha$, histamine and leukotrienes) $(6,7)$. It inhibits mobilization of granulocytes, macrophages and neutrophils and production of IgG/IgM antibodies (8). In light of the above facts, the present investigation was carried out to study the potential effect of rebamipide in the trypsin and egg-albumin induced experimental model of asthma in mice.<smiles>O=C(NC(Cc1cc(=O)[nH]c2ccccc12)C(=O)O)c1ccc(Cl)cc1</smiles>

Fig. 1. Chemical structure of rebamipide.

\section{EXPERIMENTAL}

\section{Chemicals}

Rebamipide was obtained from Macleod Pharmaceuticals, India. Dexamethasone was obtained from Suvik Pharmaceutical Private Limited, India. Trypsin and egg-albumin were purchased from Rakesh Chemicals, India. Histamine hydrochloride was procured from Sigma Chemicals, USA. Saline $(0.9 \%, m / V, \mathrm{NaCl})$ and phosphate buffered saline $(\mathrm{pH}=7.2)$ were used.

\section{Animals}

Healthy albino mice of either sex $(n=24)$, weighing 25-30 g were procured from Zydus Research Centre, India. The animals were housed at $25 \pm 1{ }^{\circ} \mathrm{C}, 50 \pm 15 \% \mathrm{RH}$ for 12 hour light-dark cycles, in polypropylene cages with free access to food and water ad libitum. The experimental protocol was approved by the Institutional (K. B. Institute of Pharmaceutical Education and Research) Animal Ethics Committee (IAEC) under the Committee for the Purpose of Control and Supervision of Experiments on Animals (CPCSEA) guideline, before carrying out the project.

\section{Study design}

A combination of trypsin and egg-albumin was used to induce asthmatic status in mice (9). The animals were divided into four groups of six animals each: group I - asthma, group II - asthma + rebamipide, group III - asthma + dexamethasone, group IV - normal control.

All animals (except group IV) were exposed to trypsin aerosol $\left(1 \mathrm{mg} \mathrm{mL}^{-1}, 1 \mathrm{~mL} \mathrm{~min}^{-1}\right)$ once daily for $5 \mathrm{~min}$, followed by a rest of $2 \mathrm{~h}$ and then exposed to egg-albumin aerosol $\left(1 \%, \mathrm{~m} / V, 1 \mathrm{~mL} \mathrm{~min}{ }^{-1}\right)$ for $3 \mathrm{~min}$. This procedure was repeated for 10 days and later egg-albumin aerosol was discontinued whereas trypsin exposure was continued until the $21^{\text {st }}$ day. On the $21^{\text {st }}$ day, after last exposure to trypsin, the animals were examined for the parameters mentioned below. Group I animals were exposed to trypsin and egg-albumin, but did not receive any drug treatment. They served as asthmatic control ani- 
P. Gohil et al.: Preliminary studies on the effect of rebamipide against the trypsin and egg-albumin induced experimental model of asthma, Acta Pharm. 61 (2011) 427-433.

mals. Animals of group II received rebamipide $\left(3 \mathrm{mg} \mathrm{kg}^{-1}\right.$, p.o. $)$ and animals of group III received dexamethasone $\left(5 \mathrm{mg} \mathrm{kg}^{-1}\right.$, p.o.) from day 22 to day 35. Group IV animals did not receive any treatment except saline and served as normal controls. On day 35, $2 \mathrm{~h}$ after of the last dose of treatment, only egg-albumin challenge was given.

On day 1 before any exposure (basal value), on day 21 after trypsin exposure and on day 35 after egg-albumin challenge, the following parameters were measured for each animal: $\mathrm{O}_{2}$, lung function (respiratory rate, air flow rate, tidal volume), blood (bicarbonate). On day 35, in addition to the above parameters, the following parameters were also measured: bronchoalveolar lavage (BAL), histamine in homogenate of lung tissue and histopathology of lung tissue.

Measurement of serum bicarbonate. - The method used in the present study to measure the serum bicarbonate level was slightly modified method described by Godkar (10).

Measurement of respiratory rate, airflow rate and tidal volume. - The measurement was done with the help of a respiratory volume transducer (11).

Differential leukocyte count in BAL fluid. - On the $35^{\text {th }}$ day, $3 \mathrm{~h}$ after the egg-albumin challenge or just prior to animal death, whichever were earlier, the tracheobronchial tree was lavaged with $1 \mathrm{~mL}$ of saline 3 to 4 times. The fluid was collected and centrifuged at $2000 \mathrm{rpm}$ for $5 \mathrm{~min}$. The supernatant was discarded and the pellet was resuspended in $0.5 \mathrm{~mL}$ saline. A thin film of suspended saline was made on a clean grease-free slide and fixed with methyl alcohol for 3-5 min and dried. Then, a few drops of Geimsa stain in phosphate buffered saline ( $\mathrm{pH}$ 6.8) were added and kept for $15 \mathrm{~min}$ or more. This was washed off with tap water and dried. The number of each type of leukocytes was determined under the microscope at $450 \times$ magnification.

Histamine release assay from lung tissues $(12,13)$ and histopathology of lungs. - On day $35,3.5 \mathrm{~h}$ after the egg-albumin challenge or just prior to death of animals, the animals were sacrificed, lungs were dissected out and chopped into fragments. Chopped lung tissues were placed in tubes with $2 \mathrm{~mL}$ of ice-cold $\mathrm{Ca}^{2+}$-free Tyrode solution and kept on ice until further use. Lung tissues ( $200 \mathrm{mg}$ wet mass) were placed into test tubes. The test tubes were then supplemented with $1.8 \mathrm{mmol} \mathrm{L}^{-1} \mathrm{CaCl}_{2}$ and incubated for $10 \mathrm{~min}$. at $37^{\circ} \mathrm{C}$. After that, the lung tissues were incubated with $2 \mathrm{mg} \mathrm{L}^{-1}$ egg-albumin for $15 \mathrm{~min}$ at $37^{\circ} \mathrm{C}$. After $15 \mathrm{~min}$, the reaction was stopped by filtration of the medium through nylon mesh $(100 \mu \mathrm{m})$. Histamine in the medium was determined fluorimetrically.

Dissected lungs were used for histopathological study.

Statistical analysis. - Experimental results were expressed as the mean $\pm \operatorname{SEM}(n=6)$. Statistical significance of the difference in parameters amongst groups was determined by one-way ANOVA followed by Tukey's multiple range test as well as by paired $t$-test.

\section{RESULTS AND DISCUSSION}

\section{Serum bicarbonate}

Challenging of animals with egg-albumin on day 35 of the study showed a significant $(p<0.001)$ higher serum bicarbonate level in the asthmatic control group compared 
P. Gohil et al.: Preliminary studies on the effect of rebamipide against the trypsin and egg-albumin induced experimental model of asthma, Acta Pharm. 61 (2011) 427-433.

Table I. Effect of dexamethasone and rebamipide on serum bicarbonate level, respiratory rate, airflow rate and tidal volume

\begin{tabular}{|c|c|c|c|c|}
\hline Parameter & Group I & Group II & Group III & Group IV \\
\hline Serum bicarbonate level $\left(\mathrm{mmol} \mathrm{L}^{-1}\right)$ & $48.83 \pm 2.39$ & $34.33 \pm 1.17^{\mathrm{a}}$ & $35.50 \pm 0.56^{\mathrm{a}}$ & $34.00 \pm 1.24^{\mathrm{b}}$ \\
\hline Respiratory rate (breaths per min) & $193.33 \pm 2.01$ & $143.50 \pm 7.79^{c}$ & $155.83 \pm 3.07^{c}$ & $168.67 \pm 4.66^{\mathrm{c}}$ \\
\hline Air-flow rate $(\mathrm{mL} \mathrm{min}-1)$ & $0.96 \pm 0.05$ & $7.29 \pm 0.55^{c}$ & $7.92 \pm 0.41^{\mathrm{c}}$ & $11.26 \pm 0.32^{c}$ \\
\hline Tidal volume $(\mathrm{mL})$ & $0.02 \pm 0.01$ & $0.05 \pm 0.02^{c}$ & $0.05 \pm 0.01^{\mathrm{c}}$ & $0.07 \pm 0.02^{c}$ \\
\hline
\end{tabular}

Values represent mean \pm SEM of six animals in each group.

Group I - asthma, group II - dexamethasone $\left(5 \mathrm{mg} \mathrm{kg}^{-1}\right)$, group III - rebamipide $\left(3 \mathrm{mg} \mathrm{kg}^{-1}\right)$, group IV - normal control.

Significant difference vs. group I: ${ }^{\mathrm{a}} p<0.05,{ }^{\mathrm{b}} p<0.01,{ }^{\mathrm{c}} p<0.001$.

to the normal control group, whereas significantly $(p<0.05)$ lower serum bicarbonate levels in dexamethasone and rebamipide-treated groups compared to the asthmatic control group (Table I).

\section{Tidal volume, respiratory rate and airflow rate}

Significantly $(p<0.001)$ lower tidal volume and air flow rate were observed in the asthmatic control group compared to the normal control group after egg-albumin challenge but there was a significant $(p<0.001)$ increase in those parameters in dexamethasone and rebamipide-treated animals. In contrast to the tidal volume and air flow rate, a significantly $(p<0.001)$ lower respiratory rate was observed in dexamethasone and rebamipide-treated groups compared to the asthmatic control group (Table I).

\section{BAL fluid}

Challenging of animals with trypsin and egg-albumin showed significantly $(p<0.001)$ higher eosinophil count in the asthmatic control group compared to the normal control

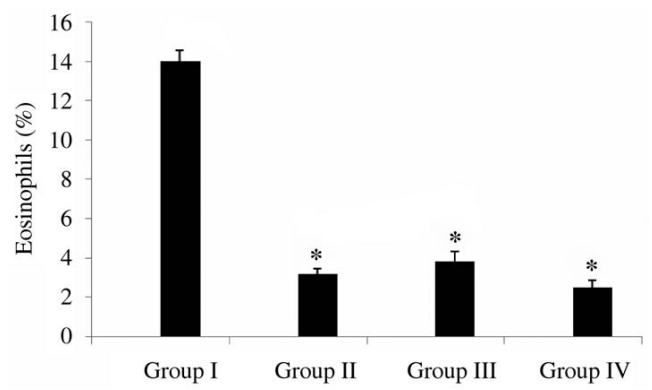

Fig. 2. Effect of dexamethasone and rebamipide on eosinophil count in BAL fluid. Values represent mean \pm SEM of six animals in each group. Group I - asthma, group II - dexamethasone $\left(5 \mathrm{mg} \mathrm{kg}^{-1}\right)$, group III - rebamipide $\left(3 \mathrm{mg} \mathrm{kg}^{-1}\right)$, group IV - normal control. Significant difference vs. group I: ${ }^{*} p<0.001$. 
group on the $35^{\text {th }}$ day of study. Also, there was a significant $(p<0.001)$ decrease in eosinophil count in the animals subjected to dexamethasone and rebamipide (Fig. 2).

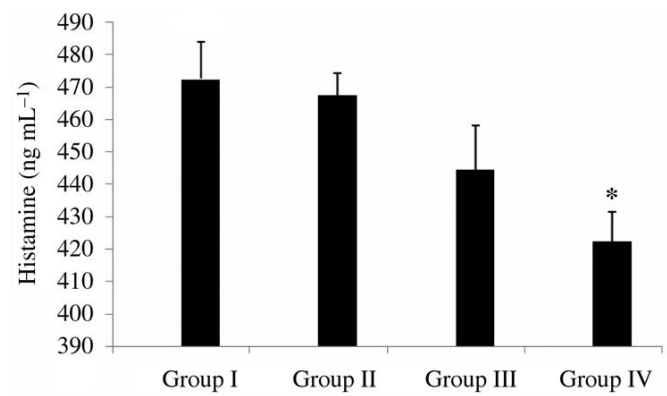

Fig. 3. Effect of dexamethasone and rebamipide on histamine concentration. Values represent mean \pm SEM of six animals in each group. Group I - asthma, group II - dexamethasone $\left(5 \mathrm{mg} \mathrm{kg}^{-1}\right)$, group III - rebamipide $\left(3 \mathrm{mg} \mathrm{kg}^{-1}\right)$, group IV - normal control. Significant difference between groups I and IV: ${ }^{*} p<0.001$.

a)

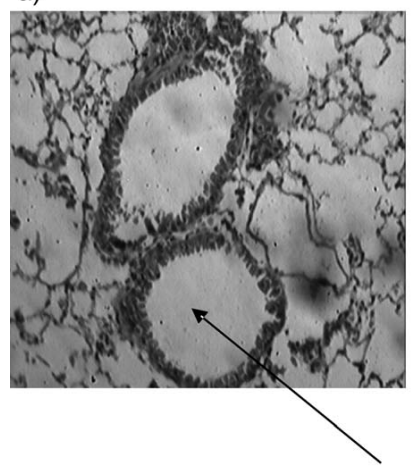

c)

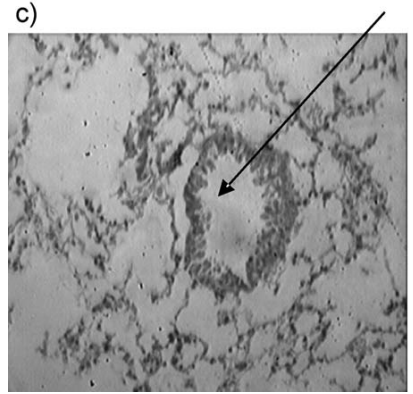

b)

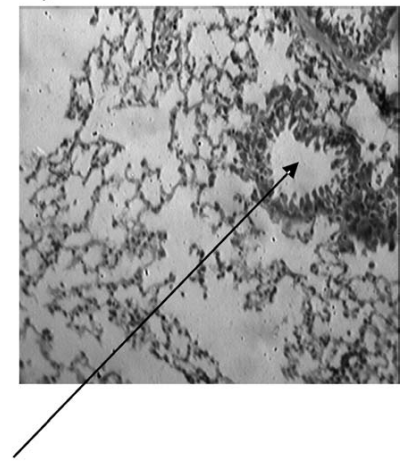

Bronchus

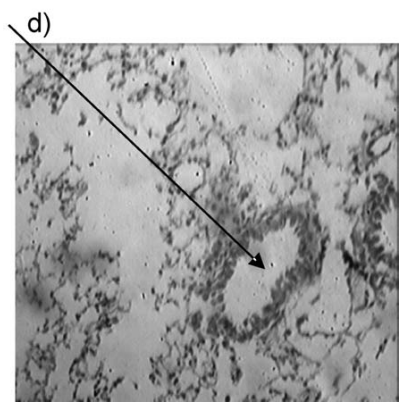

Fig. 4. Histopathology of lung: a) normal control mice, b) asthmatic mice, c) dexamethasone-treated mice, and d) rebamipide-treated mice (magnification 400×, hematoxylin stain). 
P. Gohil et al.: Preliminary studies on the effect of rebamipide against the trypsin and egg-albumin induced experimental model of asthma, Acta Pharm. 61 (2011) 427-433.

\section{Histamine release}

Significantly $(p<0.001)$ higher histamine level was observed in the asthmatic control group compared to the normal control group, but in the animals subjected to rebamipide treatment, the histamine level decreased compared to the asthmatic control group (Fig. 3).

\section{Histopathology of lungs}

Normal control animals showed an intact bronchial structure (Fig. 4a), whereas trypsin and egg-albumin-sensitized animals showed marked inflammation and destruction of bronchial wall lining (Fig. 4b). Dexamethasone and rebamipide treated animals showed minimal destruction in bronchial wall compared to the asthmatic control group (Figs. $4 \mathrm{c}$ and $4 \mathrm{~d})$.

\section{CONCLUSIONS}

It can be concluded that rebamipide has beneficial effects in trypsin and egg-albumin induced experimental bronchial asthma and might be used for its treatment. Further clinical research of rebamipide will be necessary to support the present investigation.

\section{REFERENCES}

1. NHLBI, National Asthma Education and Prevention program, Expert Panel Report 2. Guidelines for the Management of Asthma, US Department of Health and Human Services, NIH publication no: 97, 1997.

2. S. N. Georas, M. C. Liu, W. Newman, L. D. Beall, B. A. Stealey and B. S. Bochner, Altered adhesion molecule expression and endothelial cell activation accompany the recruitment of human granulocytes to the lung after segmental antigen challenge, Am. J. Respir. Cell Mol. Biol. 7 (1992) 261-269.

3. R. M. Genta, Review article: The role of rebamipide in the management of inflammatory disease of the gastrointestinal tract, Aliment. Pharm. Therap. 18 (2003) 8-13; DOI: 10.1046/j.1365-2036. 18.s1.5.

4. Y. H. Kim, H. G. Hwang and Y. T. Chung, Rebamipide protects colonic damage induced by trinitrobenzene sulfonic acid (TNBS) via down-regulation of TNF- $\alpha$, IL-1 $\alpha$, And ICAM-1, Korean J. Anat. 37 (2004) 149-155.

5. L. Kruidenier and H. W. Verspaget, Antioxidants and mucosa protectives: realistic therapeutic options in inflammatory bowel disease, Mediators Inflamm. 7 (1998) 157-162; DOI: 0962-9351/ 98/030157-06.

6. C. D. Kim, Y. K. Kim and S. H. Lee, Rebamipide inhibits neutrophil adhesion to hypoxia/reoxygenation stimulated endothelial cells via nuclear factor- $\kappa \mathrm{B}$ dependent pathway, J. Pharmacol. Exp. Ther. 294 (2000) 864-869; DOI: 0022-3565/00/2943-0864.

7. J. Y. Ro, J. Y. Kim and K. H. Kim, The inhibitory mechanism of rebamipide on the mediator release in the guinea pig lung mast cells activated with specific antigen-antibody reactions, Pharmacology 63 (2001) 175-184; DOI: 10.1159/000056130. 
P. Gohil et al.: Preliminary studies on the effect of rebamipide against the trypsin and egg-albumin induced experimental model of asthma, Acta Pharm. 61 (2011) 427-433.

8. S. Matsumoto, K. Tsuji and S. Shirahama, Rebamipide enema therapy for left-sided ischemic colitis patients accompanied by ulcers: Open label study, World J. Gastroenterol. 14 (2008) 4059-4064; DOI: 10.3748 /wjg.14.4059.

9. S. Shah, G. Shah G and P. Gohil, Role of estrogen receptor- $\alpha$ in an experimental model of bronchial asthma, Iranian Biomed. J. 14 (2010) 41-48.

10. P. B. Godkar, Acid-base Balance, in Textbook of Medical Laboratory Technology, $11^{\text {th }}$ ed., Bhalani Publishing House, New Delhi 1996, pp. 252-257.

11. R. Khandpur, Pulmonary function analyzer, in Handbook of Biomedical Instrumentation, $1^{\text {st }}$ ed., Tata McGraw-Hill Publishing Company, New Delhi 1996, pp. 308-333.

12. R. Singh, A. Nath, A. A. Gupta, M. Shukla, S. K. Khare and B. Kundu, Antiallergic/antiasthmatic effect of novel antiallergic hexapeptide-95-220 in various experimental models, Indian J. Exp. Biol. 39 (2001) 871-877.

13. P. A. Shore, A. Burkhalter and V. H. Cohn, A method for the fluorometric assay of the histamine in tissues, J. Pharmacol. Exp. Ther. 127 (1959) 182-186.

$S A \check{Z} E T A K$

\section{Preliminarno ispitivanje djelovanja rebamipida na model astme inducirane tripsinom $\mathrm{i}$ albuminom jajeta}

PRIYANSHEE GOHIL, HIMANI THAKKAR, UNNATI GOHIL i SHRIKALP DESHPANDE

U radu je ispitivano djelovanje rebamipida na eksperimentalno induciranu bronhijalnu astmu u miševa. Astma uzrokovana tripsinom i albuminom jajeta model je kronične astme. Nakon 35. dana mjereni su različiti parametri. Kontrolna skupina s astmom imala je nižu koncentraciju oksihemoglobina, dišni volumen, protok zraka, koncentraciju SOD-a, a veći broj udisaja i izdisaja, koncentraciju bikarbonata u serumu, broj eozinofila u BAL fluidu i veću koncentraciju histamina $u$ odnosu na kontrolnu skupinu bez astme. Skupina životinja tretirana deksametazonom i rebamipidom imala je veći $p \mathrm{O}_{2}$, dišni volumen, protok zraka i koncentraciju SOD-a, a smanjenu respiraciju, koncentraciju bikarbonata, broj eozinofila u BAL tekućini i koncentraciju histamina u odnosu na kontrolnu skupinu s astmom. Histopatološka ispitivanja pluća pokazala su jače izražena oštećenja alveola i mišićnog sloja u kontrolnoj skupini s astmom nego u skupini tretiranoj deksametazonom i rebamipidom. Rebamipid je imao povoljan učinak na astmatičnu skupinu i mogao bi se upotrijebiti u terapiji bronhalne astme.

Ključne riječi: astma, rebamipid, tripsin, histamin

Department of Pharmacology, K.B. Institute of Pharmaceutical Education and Research Gandhinagar, Gujarat, India

Kidney and Urology Hospital - Interstitial Cystitis Center Ahmedabad, Gujarat, India 